\title{
MIEJSCE ZAMIESZKANIA A AKCEPTACJA OSÓB Z NIEPEŁNOSPRAWNOŚCIAMI ${ }^{5}$
}

Streszczenie: Akceptacja osób z niepełnosprawnościami w społeczeństwie może być rozumiana jako jeden $\mathrm{z}$ warunków osiągnięcia równego traktowania, rzeczywistego udziału w życiu społecznym oraz rozwoju osobistego i wysokiej jakości życia tej grupy (Kazanowski, Żyta 2020). Może być analizowana pod kątem różnych czynników, zarówno zewnętrznych (demograficznych), jak i wewnętrznych. W pracy - stanowiącej część szerszego projektu badawczego - przedstawiono wyniki analizy zależności między miejscem zamieszkania a poziomem akceptacji osób z niepełnosprawnością. Wykorzystano założenia „modelu opartego na miejscu”, który uznaje lokalizację za istotny czynnik socjalizacji i tworzenia postaw (Carter i in. 2016). W badaniu wykorzystano Skalę Akceptacji Niepełnosprawności, która składa się z 27 stwierdzeń i jest narzędziem do pomiaru poziomu akceptacji osób niepełnosprawnych w trzech wymiarach: (1) akceptacji wsparcia udzielanego osobom z niepełnosprawnością; (2) akceptacji włączania osób z niepełnosprawnością w instytucje życia społecznego; (3) akceptacji kompetencji osób z niepełnosprawnością do funkcjonowania w rolach społecznych. Badaniami objęto 313 osób, w tym 156 kobiet (49,84 proc.) i 157 mężczyzn (50,16 proc.) reprezentujących trzy typy środowisk zamieszkania: wieś,

* Dr hab. Zdzisław Kazanowski, prof. uczelni, Uniwersytet Marii Curie-Skłodowskiej w Lublinie, Wydział Pedagogiki i Psychologii; e-mail: z.kazanowski@poczta.umcs.lublin.pl.

** Dr hab. Agnieszka Żyta, prof. uczelni, Uniwersytet Warmińsko-Mazurski w Olsztynie, Wydział Nauk Społecznych; e-mail: agnieszka.zyta@uwm.edu.pl.

${ }^{* * *}$ Niniejszy artykul jest rozwinięciem referatu w języku angielskim pt. Acceptance of people with disabilities and the place of residence. Polish experiences, przygotowanego na konferencje naukową 15th International Scientific Conference „Society. Integration. Education”, Rezekne, Latvija 2021. 
małe miasto i duże miasto. Wyniki badań ujawniły, że respondenci deklarowali najwyższy poziom akceptacji w zakresie włączania osób z niepełnosprawnością w instytucje życia społecznego (wymiar 2), natomiast akceptacja ich kompetencji do funkcjonowania w rolach społecznych (wymiar 3 ) była na najniższym poziomie. Ponadto zaobserwowano istotne statystycznie różnice pomiędzy grupami wyodrębnionymi ze względu na miejsce zamieszkania w zakresie natężenia akceptacji dla włączania osób niepełnosprawnych w instytucje życia społecznego.

Słowa kluczowe: akceptacja, miejsce zamieszkania, niepełnosprawność.

\section{Wprowadzenie}

Poziom akceptacji osób z niepełnosprawnościami w społeczeństwie stanowi ważny warunek inkluzji społecznej. Współczesne podejście do niepełnosprawności, oparte na biopsychospołecznej koncepcji jej przyczyn, promowaniu równych praw wszystkich obywateli, eliminowaniu marginalizacji i wykluczenia społecznego oraz stwarzaniu pełnego dostępu do zasobów społecznych w celu zapewnienia wysokiej jakości życia wszystkich ludzi, stanowi istotną przesłankę do zwiększania poziomu akceptacji tej grupy osób.

Konstrukt akceptacji jest niejednorodny, charakteryzuje się różnorodnością interpretacji i wielością definicji. Ponadto w literaturze przedmiotu podkreśla się brak kompleksowych i systematycznych ram dla zrozumienia szerszej wieloaspektowej konstrukcji akceptacji (por. Williams, JayLynn 2010). Należy też pamiętać, że akceptacja osób z niepełnosprawnościami przez pełnosprawnych członków społeczeństwa ma charakter wielowymiarowy i może być analizowana pod kątem występowania wielu czynników: zarówno zewnętrznych o charakterze demograficznym, jak i wewnętrznych (Kazanowski, Żyta 2020; Zasępa i in. 2005). Jednym z czynników zewnętrznych, wpływającym na poziom akceptacji, jest miejsce (środowisko) zamieszkania osób badanych, stanowiące nie tylko pewną przestrzeń geograficzno-społeczno-kulturową, lecz także miejsce nabywania istotnych dla kształtowania tożsamości i wyborów życiowych wartości, norm oraz wzorców zachowań. Miejsce to - w zależności od wielkości - może w różnym stopniu i zakresie wpływać na jednostkę, jej interakcje z innymi, poziom zaangażowania w życie społeczności lokalnej czy dostęp do placówek użyteczności publicznej. Jedną z poważniejszych konsekwencji wzrostu liczby mieszkańców jest m.in. zanikanie bezpośrednich interakcji i wzrost anonimowości, co pośrednio może mieć wpływ na kształtowanie relacji z innymi ludźmi lub postawy społeczne, także wobec osób $\mathrm{z}$ niepełnosprawnościami.

Niniejsze badania skupiają się na poszukiwaniu związków między akceptacją osób z niepełnosprawnościami a miejscem zamieszkania osób badanych. 


\section{Akceptacja osób z niepełnosprawnościami a „model oparty na miejscu” (ang. a place-based model) - tło teoretyczne}

Psychologia społeczna sugeruje, że akceptacja jest prawdopodobnie jednym z najważniejszych czynników wpływających na dobrostan ludzi w kontekście społecznym (DeWall, Bushman 2011). Uznaje się, że integracja społeczna jest udana, gdy osoba niepełnosprawna jest akceptowana przez innych ludzi (w tym rówieśników, sąsiadów, współpracowników itp.) jako pełnoprawny członek społeczeństwa. Akceptacja jest więc istotnym składnikiem integracji społecznej (Vornholt i in. 2013).

Jednym z elementów wpływających na postawy wobec osób z niepełnosprawnością i poziom ich akceptacji jest miejsce zamieszkania. J. Scott Carter i in. (2016, s. 272) proponują wykorzystanie „modelu opartego na miejscu, który uznaje lokalizację za istotny czynnik socjalizacji i tworzenia postaw. Model ten opiera się na pracach klasycznych badaczy, którzy podkreślali wpływ miejsca na punkty widzenia (Stouffer 1955; Wirth 1938). Zgodnie z modelem opartym na miejscu, postawy zależą bardziej od tego, czy dana osoba mieszka w pewnych miejscach, niż od tego, kiedy mieszka w tych miejscach".

W klasycznym ujęciu obszary miejskie sprzyjają bardziej kosmopolitycznym i postępowym poglądom, bardziej tolerancyjnym postawom wobec grup mniejszościowych i powszechnie marginalizowanych. Jednocześnie dominują tu relacje wtórne, a nie pierwotne, o charakterze bardziej bezosobowym. W środowisku wiejskim natomiast mieszkańcy są mniej anonimowi i bardziej narażeni na ocenę innych. Zarówno niestandardowe zachowania, jak i wygląd mogą spotykać się na wsi z mniejszą tolerancją (Carter i in. 2016; Dudak 2019). Anna Dudak (2019, s. 225-226) podaje, że „(..) w środowisku wiejskim ze względu na populację i styl życia w mniejszym stopniu niż w mieście możliwe jest zachowanie anonimowości i w związku z tym mieszkańcy są narażeni na oceny innych. Ponadto niestandardowe zachowania spotykają się z większą krytyką na wsi, gdzie nadal występuje mniejsza tolerancja wobec odmienności i odchodzenia od tradycyjnego podziału ról zawodowych i rodzinnych".

Rozróżnienie między środowiskiem wiejskim a miejskim wydaje się ważne w pewnych kontekstach kulturowych (Magiati i in. 2002). Shuang Chen, Li Ma i Jian-Xin Zhang (2011) przeprowadzili badania wśród chińskich studentów i stwierdzili, że osoby pochodzące z obszarów wiejskich mają bardziej negatywne postawy $\mathrm{w}$ porównaniu ze studentami miejskimi. Środowisko zamieszkania studentów miało wpływ na postawy implicite, natomiast na poziomie postaw explicite nie zaobserwowano różnic. Z kolei badania przeprowadzone wśród greckich uczniów w wieku 9-12 lat wykazały, że dzieci mieszkające na wsi chętniej bawią się podczas przerw w szkole z dziećmi o specjalnych potrzebach. Co więcej, dzieci wiejskie były bardziej świadome społecznych skutków własnych trudności fizycznych występujących u dzieci ze specjalnymi potrzebami (Magiati i in. 2002). Polskie badania 
wskazują na wyższy poziom gotowości do tolerowania uczniów z niepełnosprawnością intelektualną wśród młodzieży mieszkającej w dużych miastach, natomiast wyższy poziom gotowości do wspierania uczniów z niepełnosprawnością wśród mieszkańców wsi (Chodkowska, Kazanowski 2019).

\section{Metoda badań}

Cel badań miał charakter poznawczy. Chodziło o określenie poziomu akceptacji osób z niepełnosprawnością ze względu na miejsce ich zamieszkania osób badanych. Zaprojektowana diagnoza pozwoliła zarówno na ocenę zróżnicowania poziomu samej akceptacji (zmienna zależna), jak i jej porównanie w kontekście zmiennej niezależnej, jaką było miejsce zamieszkania osób uczestniczących w badaniach. Główny problem badań dotyczył poziomu akceptacji osób z niepełnosprawnością, wyrażającego się akceptowaniem udzielanego im wsparcia, poparciem dla ich uczestnictwa w życiu społecznym oraz uznaniem kompetencji wymaganych w związku z realizacją ról społecznych u osób reprezentujących różne środowiska zamieszkania.

W badaniach wykorzystano metodę sondażu diagnostycznego oraz technikę ankiety. Dzięki niej zgromadzono materiał do analiz ilościowych ukierunkowanych na osiągnięcie zaplanowanego celu. Kwestionariusz ankiety składał się z trzech części: 1) Skali Akceptacji Osób z Niepełnosprawnością; 2) Kwestionariusza Aprobaty Społecznej (KAS) i 3) informacji na temat osób uczestniczących w badaniu. Skala Akceptacji Osób z Niepełnosprawnością pozwala na zebranie materiału badawczego, który następnie może być analizowany w trzech obszarach: 1) akceptacji wsparcia udzielanego osobom $\mathrm{z}$ niepełnosprawnością; 2) akceptowania włączania osób z niepełnosprawnością do instytucji życia społecznego i 3) wyrażania akceptacji dla kompetencji osób z niepełnosprawnością do funkcjonowania w rolach społecznych. Skalę Aprobaty Społecznej zastosowano jako narzędzie służące kontrolowaniu poziomu aprobaty społecznej (por. Kazanowski 2019b; Kazanowski, Żyta 2020). Jest to istotne z powodu możliwości odpowiadania respondentów zgodnego $\mathrm{z}$ ich wyobrażeniem o oczekiwanych i aprobowanych społecznie odpowiedziach, a nie z rzeczywistym stanem rzeczy. Wiąże się również z dążeniem uczestników badań do uzyskania aprobaty społecznej (Shaughnessy i in. 2002; Weigl 1999). Kontrolując poziom aprobaty społecznej, można uniknąć poważnego źródła zniekształceń uzyskanych wyników badań. Ostatecznie po uwzględnieniu kryterium KAS (osób z liczbą punktów poniżej 7 i powyżej 21) odrzucono wyniki 41 badanych.

W badaniach uczestniczyło 313 osób, w tym 156 (49,84 proc.) kobiet i 157 (50,16 proc.) mężczyzn. Wiek badanych mieścił się w przedziale od 16 do 60 lat, a średnia wieku badanych wynosiła 35,76 lat. Szczegółową charakterystykę osób uczestniczących w badaniach zawiera tabela 1. 
Tabela 1. Charakterystyka socjodemograficzna osób uczestniczących w badaniach

\begin{tabular}{|c|c|c|}
\hline Zmienne socjodemograficzne & $\mathrm{N}$ & proc. \\
\hline \multicolumn{3}{|l|}{ Płeć badanych } \\
\hline Kobieta & 156 & 49,84 \\
\hline Mężczyzna & 157 & 50,16 \\
\hline \multicolumn{3}{|l|}{ Wiek badanych } \\
\hline 16-18 lat & 97 & 30,99 \\
\hline $31-40$ lat & 107 & 35,14 \\
\hline pow. 5o lat & 106 & 33,87 \\
\hline \multicolumn{3}{|l|}{ Miejsce zamieszkania } \\
\hline Wieś & 116 & 37,06 \\
\hline Małe miasto & 93 & 29,71 \\
\hline Duże miasto & 104 & 33,23 \\
\hline \multicolumn{3}{|l|}{ Wykształcenie matki } \\
\hline Podstawowe & 45 & 14,38 \\
\hline Zawodowe & 96 & 30,67 \\
\hline Średnie & 108 & 34,50 \\
\hline Wyższe & 64 & 20,45 \\
\hline \multicolumn{3}{|l|}{ Wykształcenie ojca } \\
\hline Podstawowe & 50 & 15,97 \\
\hline Zawodowe & 126 & 40,26 \\
\hline Średnie & 81 & 25,88 \\
\hline Wyższe & 51 & 16,29 \\
\hline Brak odpowiedzi & 5 & 1,60 \\
\hline \multicolumn{3}{|l|}{ Zatrudnienie matki* } \\
\hline Nie pracuje & 109 & 34,82 \\
\hline Pracuje & 142 & 45,37 \\
\hline Brak odpowiedzi & 62 & 19,81 \\
\hline \multicolumn{3}{|l|}{ Zatrudnienie ojca* } \\
\hline Nie pracuje & 66 & 21,09 \\
\hline Pracuje & 179 & 57,19 \\
\hline Brak odpowiedzi & 68 & 21,72 \\
\hline \multicolumn{3}{|l|}{ Struktura środowiska rodzinnego ${ }^{* *}$} \\
\hline Rodzina pełna & 279 & 87,14 \\
\hline Rodzina niepełna & 34 & 10,86 \\
\hline \multicolumn{3}{|l|}{ Posiadanie rodzeństwa } \\
\hline Tak & 247 & 78,91 \\
\hline Nie & 66 & 21,09 \\
\hline \multicolumn{3}{|l|}{ Osoby z niepełnosprawnością w rodzinie } \\
\hline Tak & 45 & 14,38 \\
\hline Nie & 267 & 85,30 \\
\hline Brak odpowiedzi & 1 & 0,32 \\
\hline \multicolumn{3}{|c|}{ Kontakty z uczniami z niepełnosprawnością w szkole podstawowej } \\
\hline Tak & 34 & 10,86 \\
\hline
\end{tabular}




\begin{tabular}{|l|c|c|}
\hline \multicolumn{1}{|c|}{ Zmienne socjodemograficzne } & N & proc. \\
\hline Nie & 269 & 3,94 \\
\hline Brak odpowiedzi & 10 & 3,20 \\
\hline Kontakty z uczniami z niepełnosprawnością w gimnazjum & 20 & 6,39 \\
\hline Tak & 249 & 79,55 \\
\hline Nie & 44 & 14,06 \\
\hline Brak odpowiedzi & 24 & 7,67 \\
\hline Kontakty z uczniami z niepełnosprawnością w szkole średniej & 91,05 \\
\hline Tak & 285 & 1,28 \\
\hline Nie & 4 & \\
\hline Brak odpowiedzi & 68 & 21,73 \\
\hline Kontakty z osobami z niepełnosprawnością w środowisku lokalnym & 77,95 \\
\hline Tak & 244 & 0,32 \\
\hline Nie & 1 & \\
\hline Brak odpowiedzi & 68 \\
\hline
\end{tabular}

* W przypadku drugiej i trzeciej grupy wiekowej chodzi o okres przypadający na wiek rozwojowy.

** W przypadku drugiej i trzeciej grupy wiekowej chodzi o rodzinę pochodzenia, w której wychowywały się badane osoby będąc w wieku rozwojowym.

W badaniach zastosowano dobór próby probabilistyczny warstwowy. W trakcie spotkań zorganizowanych w wytypowanych klasach na terenie szkoły proszono uczniów o wzięcie udziału w badaniach oraz wręczano każdemu z nich trzy egzemplarze kwestionariusza (jeden dla ucznia i dwa dla innych osób dorosłych wspólnie zamieszkujących) do wypełnienia w domu. W statystycznej analizie wyników badań wykorzystano analizę wariancji oraz test RIR Tukeya.

\section{Analiza wyników badań}

W analizie wyników badań porównano deklarowane przez badanych natężenie akceptacji odnoszącej się do osób z niepełnosprawnością ze względu miejsce zamieszkania. Uwzględniono również strukturę mierzonej akceptacji, kierując uwagę na analizę wyników badań odnoszących się do trzech obszarów badanej zmiennej zależnej. 
Tabela 2. Wyniki analizy akceptacji osób z niepełnosprawnością ze względu na miejsce zamieszkania

\begin{tabular}{|l|c|c|c|c|c|c|c|c|}
\hline \multirow{2}{*}{$\begin{array}{l}\text { Zmienna: akceptacja osób } \\
\text { z niepełnosprawnością }\end{array}$} & \multicolumn{2}{|c|}{$\begin{array}{c}\text { Miejsce } \\
\text { zamieszkania } \\
- \text { - wieś }\end{array}$} & \multicolumn{2}{|c|}{$\begin{array}{c}\text { Miejsce } \\
\text { zamieszkania - } \\
\text { małe miasto }\end{array}$} & \multicolumn{2}{|c|}{$\begin{array}{c}\text { Miejsce } \\
\text { zamieszkania - } \\
\text { duże miasto }\end{array}$} & F & p \\
\cline { 2 - 9 } & $M$ & $S D$ & $M$ & $S D$ & $M$ & $S D$ & \\
\hline $\begin{array}{l}\text { Czynnik 1: } \\
\text { akceptowanie wsparcia } \\
\text { udzielanego osobom } \\
\text { z niepełnosprawnością }\end{array}$ & 3,52 & 0,56 & 3,53 & 0,50 & 3,63 & 0,68 & 1,060 & 0,348 \\
\hline $\begin{array}{l}\text { Czynnik 2: akceptowanie } \\
\text { włączania osób } \\
\text { z niepełnosprawnością } \\
\text { do instytucji życia } \\
\text { społecznego }\end{array}$ & 3,95 & 0,68 & 3,88 & 0,75 & 4,12 & 0,65 & 3,170 & $0,043^{*}$ \\
\hline $\begin{array}{l}\text { Czynnik 3: akceptowanie } \\
\text { kompetencji osób } \\
\text { z niepełnosprawnością do } \\
\text { funkcjonowania w rolach } \\
\text { społecznych }\end{array}$ & 3,26 & 0,55 & 3,27 & 0,61 & 3,37 & 0,65 & 1,076 & 0,342 \\
\hline
\end{tabular}

* Różnice istotne statystycznie między osobami mieszkającymi w małym mieście i w dużym mieście $(\mathrm{p}=0,039)$.

Analizując dane zamieszczone w tabeli 2, można zauważyć, iż występuje istotna statystycznie różnica w zakresie akceptacji włączania osób z niepełnosprawnością do instytucji życia społecznego między osobami, które mieszkają w małym mieście, a tymi, które zamieszkują duże miasta $(\mathrm{p}=0,039)$. Na podkreślenie zasługuje fakt, że to właśnie osoby zamieszkujące małe miasta w mniejszym stopniu zgadzają się na włączanie osób z niepełnosprawnością do instytucji życia społecznego $(\mathrm{M}=3,88)$. Warto także podkreślić, iż we wszystkich wyodrębnionych grupach najniższe wyniki odnoszą sie do oceny przygotowania osób z niepełnosprawnością do pełnienia ról społecznych, a najwyższe do akceptowania włączania osób z niepełnosprawnością do instytucji życia społecznego. Zauważyć można także, iż badani mieszkający w dużym mieście, deklarują wyższy ogólny poziom akceptacji osób z niepełnosprawnością $(M=3,71)$ niż badani mieszkający w małych miastach $(M=3,56)$ lub na wsi $(M=3,58)$. Gdyby zaś połączyć osoby mieszkające w miastach w jedną grupę, okazałoby się, że ogólny poziom akceptacji osób z niepełnosprawnością u badanych mieszkających w mieście $(M=3,63)$ jest wyższy niż u badanych mieszkających na wsi $(M=3,58)$. Różnice w tym przypadku nie osiągają wprawdzie wartości istotnej statystycznie, lecz zachęcają do przeprowadzenia bardziej szczegółowych analiz i poszukiwania różnic międzygrupowych także w zakresie poszczególnych wymiarów akceptacji na poziomie itemów zastosowanego kwestionariusza. 
Tabela 3. Wyniki analizy akceptacji wsparcia udzielanego osobom z niepełnosprawnością ze względu na miejsce zamieszkania

\begin{tabular}{|c|c|c|c|c|c|c|c|c|}
\hline \multirow{2}{*}{$\begin{array}{c}\text { Czynnik 1: } \\
\text { akceptowanie wsparcia } \\
\text { udzielanego osobom } \\
\text { z niepełnosprawnością }\end{array}$} & \multicolumn{2}{|c|}{$\begin{array}{c}\text { Miejsce } \\
\text { zamieszkania - } \\
\text { wieś }\end{array}$} & \multicolumn{2}{|c|}{$\begin{array}{c}\text { Miejsce zamiesz- } \\
\text { kania - małe } \\
\text { miasto }\end{array}$} & \multicolumn{2}{|c|}{$\begin{array}{c}\text { Miejsce zamiesz- } \\
\text { kania - duże } \\
\text { miasto }\end{array}$} & \multirow[t]{2}{*}{$\mathrm{F}$} & \multirow[t]{2}{*}{$\mathrm{p}$} \\
\hline & $M$ & $S D$ & $M$ & $S D$ & $M$ & $S D$ & & \\
\hline $\begin{array}{l}\text { Osoby } \\
\text { z niepełnosprawnością } \\
\text { tworzą wybitne działa } \\
\text { sztuki }\end{array}$ & 3,70 & 0,94 & 3,60 & 1,03 & 3,73 & 1,01 & 0,442 & 0,643 \\
\hline $\begin{array}{l}\text { Przekazałbym } \\
\text { środki finansowe na } \\
\text { wsparcie dla osób } \\
\text { z niepełnosprawnością }\end{array}$ & 3,12 & 1,01 & 3,54 & 0,88 & 3,18 & 1,12 & 4,876 & $0,008^{\star}$ \\
\hline $\begin{array}{l}\text { Brak specjalnych } \\
\text { udogodnień dla } \\
\text { niepełnosprawnych } \\
\text { w szkołach zmniejsza } \\
\text { liczbę uczniów } \\
\text { z niepełnosprawnością } \\
\text { w instytucjach } \\
\text { ogólnodostępnych }\end{array}$ & 3,58 & 0,99 & 3,65 & 0,99 & 3,76 & 1,11 & 0,868 & 0,421 \\
\hline $\begin{array}{l}\text { Chętnie poszedłbym/ } \\
\text { abym na spektakl, } \\
\text { w którym } \\
\text { występują osoby } \\
\text { z niepełnosprawnością }\end{array}$ & 3,41 & 1,00 & 3,52 & 1,06 & 3,66 & 1,06 & 1,601 & 0,203 \\
\hline $\begin{array}{l}\text { Osoby } \\
\text { z niepełnosprawnością } \\
\text { powinny mieć } \\
\text { pierwszeństwo } \\
\text { w dostępie do opieki } \\
\text { i pomocy medycznej }\end{array}$ & 3,67 & 1,09 & 3,51 & 0,98 & 3,52 & 1,18 & 0,787 & 0,456 \\
\hline $\begin{array}{l}\text { Za trudności } \\
\text { w dostępie osób } \\
\text { z niepełnosprawnością } \\
\text { do instytucji } \\
\text { publicznych } \\
\text { odpowiadają osoby } \\
\text { pełnosprawne }\end{array}$ & 3,72 & 0,94 & 3,70 & 1,00 & 3,84 & 1,11 & 0,563 & 0,570 \\
\hline $\begin{array}{l}\text { Osoby } \\
\text { z niepełnosprawnością } \\
\text { powinny mieć } \\
\text { zapewnioną możliwość } \\
\text { bezpłatnego udziału } \\
\text { w imprezach } \\
\text { kulturalnych }\end{array}$ & 3,15 & 1,10 & 3,04 & 1,07 & 3,39 & 1,14 & 2,690 & 0,069 \\
\hline
\end{tabular}




\begin{tabular}{|c|c|c|c|c|c|c|c|c|}
\hline \multirow{2}{*}{$\begin{array}{c}\text { Czynnik 1: } \\
\text { akceptowanie wsparcia } \\
\text { udzielanego osobom } \\
\text { z niepełnosprawnością }\end{array}$} & \multicolumn{2}{|c|}{\begin{tabular}{|c|} 
Miejsce \\
zamieszkania - \\
wieś
\end{tabular}} & \multicolumn{2}{|c|}{$\begin{array}{c}\text { Miejsce zamiesz- } \\
\text { kania - małe } \\
\text { miasto }\end{array}$} & \multicolumn{2}{|c|}{$\begin{array}{c}\text { Miejsce zamiesz- } \\
\text { kania - duże } \\
\text { miasto } \\
\end{array}$} & \multirow[t]{2}{*}{$F$} & \multirow[t]{2}{*}{$\mathrm{p}$} \\
\hline & $M$ & $S D$ & $M$ & $S D$ & $M$ & $S D$ & & \\
\hline $\begin{array}{l}\text { W programie } \\
\text { szkolnym } \\
\text { należy umieścić } \\
\text { wizerunki osób } \\
\text { z niepełnosprawnością }\end{array}$ & 3,44 & 0,91 & 3,49 & 0,87 & 3,53 & 1,01 & 0,257 & 0,774 \\
\hline \begin{tabular}{|l|} 
Osiągnięcia osób \\
z niepełnosprawnością \\
są ważne dla rozwoju \\
społeczeństwa \\
\end{tabular} & 3,53 & 0,80 & 3,29 & 1,08 & 3,69 & 1,02 & 4,288 & $0,015^{* *}$ \\
\hline \begin{tabular}{|l|} 
Społeczeństwo \\
ma obowiązek \\
likwidować przeszkody \\
utrudniające swobodne \\
poruszanie się osobom \\
z niepełnosprawnością \\
\end{tabular} & 4,14 & 0,98 & 4,09 & 0,96 & 4,10 & 1,18 & 0,075 & 0,928 \\
\hline \begin{tabular}{|l|} 
Potrzebne są \\
miejsca, w których \\
można zapoznać się \\
z osiągnięciami osób \\
z niepełnosprawnością
\end{tabular} & 3,27 & 0,90 & 3,42 & 0,94 & 3,49 & 1,17 & 1,412 & 0,245 \\
\hline
\end{tabular}

Szczegółowa analiza akceptacji wsparcia udzielanego osobom z niepełnosprawnością (tabela 3) ujawniła istotne statystycznie zróżnicowanie poglądów między osobami reprezentującymi różne kategorie środowiska zamieszkania. Ustalono, że osoby zamieszkujące małe miasta charakteryzują się istotnie wyższym poziomem gotowości do udzielenia wsparcia finansowego osobom z niepełnosprawnością $(\mathrm{p}=0,008)$ niż osoby zamieszkujące wieś i duże miasto, co można interpretować jako zrozumienie dla konieczności ponoszenia wyższych kosztów związanych z zaspokajaniem potrzeb przez te osoby. Wprawdzie wartość średniej $(M=3,54)$ nie uprawnia do wykazania wysokiego natężenia tej cechy, można ją jednak uznać za ważny komponent dla akceptacji wsparcia udzielanego osobom z niepełnosprawnością przez tę grupę badanych.

Różnica istotna statystycznie wystąpiła także w odniesieniu do oceny osiągnięć osób z niepełnosprawnością $(\mathrm{p}=\mathrm{o}, 015)$. Uznawanie osiągnięć osób $\mathrm{z}$ niepełnosprawnością, jako ważnych dla rozwoju społeczeństwa, jest charakterystyczne dla mieszkańców dużych miast $(M=3,69)$. Wynik ten wyraźnie koresponduje z przekonaniem o występowaniu wybitnych osiągnięć wśród osób z niepełnosprawnością w obszarze twórczości artystycznej $(\mathrm{M}=3,73)$. Szacunek dla wysiłku 
podejmowanego przez osoby z niepełnosprawnością i pozytywna opinia o jego rezultatach, wyróżniają akceptację mieszkańców dużych miast odnoszącą się do udzielania wsparcia tym osobom $\mathrm{w}$ porównaniu $\mathrm{z}$ mieszkańcami małych miast $(\mathrm{p}=\mathrm{o}, \mathrm{010})$.

Tabela 4. Wyniki analizy akceptacji włączania osób z niepełnosprawnością do instytucji życia społecznego ze względu na miejsce zamieszkania

\begin{tabular}{|c|c|c|c|c|c|c|c|c|}
\hline \multirow{2}{*}{$\begin{array}{c}\text { Czynnik 2: akceptowanie } \\
\text { włączania osób } \\
\text { z niepełnosprawnością do } \\
\text { instytucji życia społecznego }\end{array}$} & \multicolumn{2}{|c|}{$\begin{array}{c}\text { Miejsce } \\
\text { zamieszka- } \\
\text { nia - wieś }\end{array}$} & \multicolumn{2}{|c|}{$\begin{array}{l}\text { Miejsce za- } \\
\text { mieszkania - } \\
\text { małe miasto }\end{array}$} & \multicolumn{2}{|c|}{$\begin{array}{c}\text { Miejsce } \\
\text { zamieszkania - } \\
\text { duże miasto } \\
\end{array}$} & \multirow[t]{2}{*}{ F } & \multirow[t]{2}{*}{$\mathrm{p}$} \\
\hline & $M$ & $S D$ & $M$ & $S D$ & $M$ & $S D$ & & \\
\hline $\begin{array}{l}\text { Osiągnięcia osób } \\
\text { z niepełnosprawnością } \\
\text { zasługują na upublicznienie }\end{array}$ & 4,10 & 1,11 & 3,98 & 1,22 & 4,47 & 0,81 & 5,959 & $0,003^{*}$ \\
\hline $\begin{array}{l}\text { Osoby } \\
\text { z niepełnosprawnością } \\
\text { powinny zawierać związki } \\
\text { małżeńskie }\end{array}$ & 3,87 & 1,16 & 4,01 & 1,13 & 4,20 & 1,00 & 2,495 & 0,084 \\
\hline $\begin{array}{l}\text { Osoby } \\
\text { z niepełnosprawnością } \\
\text { powinny mieć } \\
\text { zagwarantowany } \\
\text { dostęp do dóbr i usług } \\
\text { umożliwiających pełne } \\
\text { uczestnictwo w życiu } \\
\text { społecznym }\end{array}$ & 4,20 & 0,84 & 4,11 & 0,93 & 4,30 & 0,82 & 1,211 & 0,299 \\
\hline $\begin{array}{l}\text { Uczniowie pełnosprawni } \\
\text { powinni w szkole } \\
\text { kontaktować się } \\
\text { z niepełnosprawnymi } \\
\text { rówieśnikami }\end{array}$ & 4,28 & 0,94 & 4,05 & 1,16 & 4,26 & 1,11 & 1,330 & 0,266 \\
\hline $\begin{array}{l}\text { Osoby } \\
\text { z niepełnosprawnością } \\
\text { powinny korzystać } \\
\text { z pełnego prawa do } \\
\text { edukacji w szkołach } \\
\text { ogólnodostępnych }\end{array}$ & 3,85 & 1,07 & 3,76 & 0,99 & 4,10 & 0,98 & 2,889 & 0,057 \\
\hline $\begin{array}{l}\text { Osoby } \\
\text { z niepełnosprawnością } \\
\text { powinny pokazywać } \\
\text { publicznie swoje uczucia }\end{array}$ & 3,72 & 1,27 & 3,75 & 1,10 & 4,02 & 1,13 & 2,096 & 0,125 \\
\hline
\end{tabular}




\begin{tabular}{|l|c|c|c|c|c|c|c|c|}
\hline $\begin{array}{l}\text { Osoby } \\
\text { Z niepełnosprawnością } \\
\text { ograniczają dostęp innym } \\
\text { do świadczeń opieki } \\
\text { medycznej* }\end{array}$ & 3,66 & 1,01 & 3,48 & 1,07 & 3,49 & 1,27 & 0,907 & 0,405 \\
\hline
\end{tabular}

* Różnice istotne statystycznie między osobami mieszkającą na wsi i w dużym mieście (p = 0,027) oraz między osobami mieszkającymi w małych i dużych miastach $(\mathrm{p}=0,003)$.

Analizując akceptację odnoszącą się do włączania osób z niepełnosprawnością do instytucji życia społecznego (tabela 4), stwierdzono występowanie istotnej statystycznie różnicy w odniesieniu do potrzeby upowszechniania osiągnięć osób z niepełnosprawnością $(\mathrm{p}=0,003)$. Osoby mieszkające $\mathrm{w}$ dużym mieście reprezentują istotnie wyższy poziom przekonania o potrzebie upowszechniania osiągnięć osób $\mathrm{z}$ niepełnosprawnością $(\mathrm{M}=4,47)$ w porównaniu z grupami osób reprezentujących pozostałe środowiska zamieszkania.

Tabela 5. Wyniki analizy akceptacji kompetencji osób z niepełnosprawnością do funkcjonowania w rolach społecznych ze względu na miejsce zamieszkania

\begin{tabular}{|c|c|c|c|c|c|c|c|c|}
\hline \multirow{2}{*}{$\begin{array}{l}\text { Czynnik 3: akceptowanie } \\
\text { kompetencji osób } \\
\text { z niepełnosprawnością do } \\
\text { funkcjonowania w rolach } \\
\text { społecznych }\end{array}$} & \multicolumn{2}{|c|}{$\begin{array}{l}\text { Miejsce za- } \\
\text { mieszkania - } \\
\text { wieś }\end{array}$} & \multicolumn{2}{|c|}{$\begin{array}{c}\text { Miejsce } \\
\text { zamieszkania } \\
\text { - małe miasto }\end{array}$} & \multicolumn{2}{|c|}{$\begin{array}{c}\text { Miejsce } \\
\text { zamieszkania - } \\
\text { duże miasto }\end{array}$} & \multirow[t]{2}{*}{$\mathrm{F}$} & \multirow[t]{2}{*}{$\mathrm{p}$} \\
\hline & $M$ & $S D$ & $M$ & $S D$ & $M$ & $S D$ & & \\
\hline $\begin{array}{l}\text { Uczniowie } \\
\text { z niepełnosprawnością } \\
\text { powinni mieć możliwość } \\
\text { kształcenia się w dowolnej } \\
\text { szkole }\end{array}$ & 3,91 & 1,12 & 3,75 & 1,18 & 4,00 & 1,07 & 1,225 & 0,295 \\
\hline $\begin{array}{l}\text { Osoby z niepełnosprawnością } \\
\text { są mniej wydajnymi } \\
\text { pracownikami niż osoby } \\
\text { pełnosprawne* }\end{array}$ & 3,15 & 0,96 & 3,19 & 1,20 & 3,56 & 1,20 & 4,285 & $0,015^{*}$ \\
\hline $\begin{array}{l}\text { Rodzic z niepełnosprawnością } \\
\text { jest w stanie zapewnić } \\
\text { swojemu dziecku takie same } \\
\text { warunki wychowania jak } \\
\text { rodzic pełnosprawny }\end{array}$ & 3,12 & 1,11 & 3,24 & 1,17 & 3,27 & 1,32 & 0,466 & 0,628 \\
\hline $\begin{array}{l}\text { Mógłbym/mogłabym } \\
\text { współpracować z osobą } \\
\text { z niepełnosprawnością } \\
\text { w realizacji ważnego zadania }\end{array}$ & 3,79 & 0,93 & 3,70 & 0,94 & 3,63 & 1,07 & 0,727 & 0,484 \\
\hline $\begin{array}{l}\text { W każdej instytucji powinny } \\
\text { być zatrudniane osoby } \\
\text { z niepełnosprawnością }\end{array}$ & 2,95 & 1,01 & 2,87 & 1,00 & 2,74 & 1,02 & 1,169 & 0,312 \\
\hline
\end{tabular}




\begin{tabular}{|l|c|c|c|c|c|c|c|c|}
\hline $\begin{array}{l}\text { Poparłbym kandydaturę osoby } \\
\text { z niepełnosprawnością na } \\
\text { stanowisko kierownicze }\end{array}$ & 3,34 & 0,98 & 3,34 & 0,94 & 3,51 & 1,04 & 1,028 & 0,359 \\
\hline $\begin{array}{l}\text { Małżeństwa osób } \\
\text { z niepełnosprawnością nie } \\
\text { różnią się od małżeństw osób } \\
\text { pełnosprawnych }\end{array}$ & 3,39 & 1,09 & 3,54 & 1,11 & 3,38 & 1,14 & 0,602 & 0,548 \\
\hline $\begin{array}{l}\text { Mając możliwość wyboru } \\
\text { przyszłego pracownika, } \\
\text { lepiej zatrudnić osobę } \\
\text { z niepełnosprawnością niż } \\
\text { pełnosprawną }\end{array}$ & 2,67 & 0,88 & 2,74 & 0,93 & 2,89 & 0,97 & 1,613 & 0,201 \\
\hline $\begin{array}{l}\text { Osoby z niepełnosprawnością } \\
\text { mają duży potencjał do } \\
\text { kierowania organizacjami } \\
\text { społecznymi }\end{array}$ & 3,01 & 0,91 & 3,09 & 0,76 & 3,35 & 0,97 & 4,217 & $0,016^{* *}$ \\
\hline
\end{tabular}

* Różnice istotne statystycznie między osobami mieszkającymi na wsi i w dużym mieście ( $\mathrm{p}=0,018)$.

** Różnice istotne statystycznie między osobami mieszkającymi na wsi i w dużym mieście ( $\mathrm{p}=0,014)$.

Analiza akceptacji kompetencji osób z niepełnosprawnością do funkcjonowania w rolach społecznych (tabela 5) ujawniła istotne statystycznie różnice między badanymi grupami w zakresie oceny wydajności osób z niepełnosprawnością $(\mathrm{p}=0,015)$ oraz ich zdolności do kierowania organizacjami społecznymi $(\mathrm{p}=0,016)$. Największe różnice wystąpiły między osobami mieszkającymi na wsi i w dużym mieście, przy czym mieszkańcy dużych miast bardziej pozytywnie oceniali potencjał osób z niepełnosprawnością do kierowania organizacjami społecznymi, zaś mieszkający na wsi bardziej pozytywnie postrzegali wydajność tej grupy osób. Wystąpiła więc w tym wymiarze ambiwalencja ocen, co jest zjawiskiem typowym, biorąc pod uwagę postawy wobec osób z niepełnosprawnością.

\section{Dyskusja i wnioski}

Poziom akceptacji w odniesieniu do osób niepełnosprawnych jest zróżnicowany w zależności od miejsca zamieszkania uczestników badania, co oznacza, że miejsce zamieszkania może być uznane za ważną zmienną wyjaśniającą trudności w integracji osób z niepełnosprawnością ze społecznością lokalną.

Nasze badania potwierdzają, że poziom akceptacji osób niepełnosprawnych wśród osób mieszkających w dużych miastach jest zazwyczaj wyższy niż wśród osób mieszkających na wsi czy w małych miastach i osiąga znacząco wyższy poziom wsparcia dla ich uczestnictwa w życiu społecznym. Wydaje się to potwierdzać zarówno klasyczne podejścia do wpływu środowiska miejskiego na mniej wykluczające postawy wobec grup marginalizowanych (Carter i in. 2016), jak i wcześniejsze badania polskie czy chińskie (Chen i in. 2011; Chodkowska, Kazanowski 2019). W środowisku miejskim interakcje w sferze publicznej zachodzą głównie 
między nieznajomymi ludźmi, którzy nie znają się nawzajem w sposób intymny. Wielokrotne interakcje z innymi, którzy różnią się kategorialnie, prowadzi do większej tolerancji. Ludzie uczą się, że „mogą działać razem... bez konieczności bycia takimi samymi” (Lofland 1998, s. 242, za: Huggins, Debies-Carl 2014). Tłumaczyć to może m.in. większy poziom akceptacji wobec oceny potencjału osób z niepełnosprawnościami czy uznawania ich osiągnięć (zwłaszcza artystycznych) oraz potrzeby ich upowszechniania wśród mieszkańców dużych miast. Ponadto to zwykle w środowisku miejskim funkcjonują różne centra wsparcia, stowarzyszenia osób i opiekunów osób z niepełnosprawnościami, fundacje, placówki terapeutyczno-rehabilitacyjne, oraz galerie czy teatry, gdzie prezentowane są prace oraz przedstawienia, których twórcami/aktorami są osoby z niepełnosprawnościami. Częstszy kontakt z tą grupą osób, wliczaną do zwykłych mieszkańców z najbliższego środowiska, uczestniczących w codziennym życiu, jak również twórczych i autonomicznych, może pozytywnie wpływać na poziom akceptacji.

$\mathrm{Z}$ drugiej strony inne badania donoszą o bardziej pozytywnych postawach wobec uczniów z niepełnosprawnością wśród dzieci mieszkających w środowiskach wiejskich (Gash, Coffey 1995; Magiati i in. 2002). Może to sugerować, że oprócz miejsca zamieszkania (liczba mieszkańców zamieszkujących daną miejscowość, rodzaj stosunków panujących w danym środowisku, dostęp do obiektów użyteczności publicznej) istotną rolę odgrywa kontekst kulturowy. Mimo postępującej globalizacji, pewne różnice kulturowe (np. zakorzenienie w historii czy dominującej religii) mogą wpływać na różnice w wynikach między krajami. Istotne mogą być różnice $\mathrm{w}$ relacjach społecznych i rodzinnych, rytmie życia, interakcji ze środowiskiem naturalnym i szerszą społecznością (Magiati i in. 2002).

\section{Zakończenie}

Wyniki naszych badań sugerują, że warto korzystać z danych na temat miejsca zamieszkania w kształtowaniu akceptacji wobec osób z niepełnosprawnością. Prezentowanie wyników aktywności własnej osób z niepełnosprawnością może okazać się w tym przypadku bardziej skuteczne niż koncentrowanie się na ograniczeniach i odkrywanie barier w podejmowaniu aktywności i zaspokajaniu potrzeb. Niezbędna wydaje się również kontynuacja badań i próba wyjaśnienia różnic w poziomie akceptacji osób niepełnosprawnych ze względu na miejsce zamieszkania. Ważnym elementem może być wspieranie budowania wspólnoty lokalnej opartej na kontaktach nieformalnych, wspólnym spędzaniu czasu wolnego, propagowania wolontariatu i działalności społecznej na rzecz osób potrzebujących (m.in. starszych czy niepełnosprawnościami). Poczucie solidarności społecznej i odpowiedzialności za osoby współtworzące środowisko lokalne może stanowić czynnik sprzyjający wzrostowi poziomu akceptacji wobec różnych grup zagrożonych marginalizacją, w tym także osób z niepełnosprawnością. 


\section{Bibliografia}

Carter J.S., Carter S.K., Corra M. (2016). The significance of place: The impact of urban and regional residence on gender-role attitudes. „Sociological Focus”, nr 49 (4), s. 271-285.

Chen S., Ma L., Zhang J.-X. (2011). Chinese Undergraduates' Explicit and Implicit Attitudes Toward Persons With Disabilities. „Rehabilitation Counseling Bulletin”, nr 55 (1), s. 38-45.

Chodkowska M., Kazanowski Z. (2019). Gotowość młodzieży do integracji szkolnej z uczniem z niepetnosprawnościa intelektualna. Lublin: Wydawnictwo UMCS.

Devine M.A. (2004). „Being a «Doer» Instead of a «Viewer»": The Role of Inclusive Leisure Contexts in Determining Social Acceptance for People with Disabilities. „Journal of Leisure Research", nr 36 (2), s. 137-159.

DeWall C.N., Bushman B.J. (2011). Social acceptance and rejection: the sweet and the bitter. „Current Directions in Psychological Science”, nr 20 (4), s. 256-6o.

Dudak A. (2019). Mężczyźni w zawodach sfeminizowanych - funkcjonujące stereotypy i ich konsekwencje w percepcji studentów. „Annales Universitatis Mariae Curie-Skłodowska", vol. XXXII (4), s. 217-230.

Gash H., Coffey D. (1995). Influences on attitudes towards children with mental handicap. „European Journal of Special Needs Education”, nr 10, s. 1-16.

Huggins Ch., M., Debies-Carl J.S. (2014). Tolerance in the city: the multilevel effects of urban environments on permissive attitudes. "Journal of Urban Affairs", nr 3 (37), s. 255-269.

Kazanowski Z. (2019a). Postawy wobec integracji społecznej osób z niepełnosprawnościa w kontekście zmiany pokoleniowej. „Edukacja-Technika-Informatyka”, nr 1 (27), s. 255-26o.

Kazanowski Z. (2019b). Wielowymiarowość postaw wobec integracji społecznej osób $z$ niepetnosprawnością. „Edukacja-Technika-Informatyka”, nr 1 (27), s. $243-248$.

Kazanowski Z., Żyta A. (2020). Akceptacja osób z niepełnosprawnościq a doświadczenia integracyjne w szkole. „Forum Pedagogiczne”, t. 10, nr 2, s. 121-133

Magiati, I., Dockrell, J.E., Logotheti, A.-E. (2002). Young children's understanding of disabilities: the influence of development, context, and cognition. „Applied Developmental Psychology", nr 23, s. 409-430

Morin D., Rivard M., Crocker A.G., Boursier C.P., Caron J. (2013). Public attitudes towards intellectual disability: a multidimensional perspective. "Journal of Intellectual Disability Research", nr 57, cz. 3, s. 279-292.

Shaughnessy J.J., Zechmeister E.B., Zechmeister J.S. (2002). Metody badawcze w psychologii. Gdańsk: GWP.

Stouffer S. (1955). Communism, Conformity, and Civil Liberties. New York: Doubleday. 
Vornholt K., Uitdewilligen S., Nijhuis F.J. N. (2013). Factors Affecting the Acceptance of People with Disabilities at Work: A Literature Review. "Journal of Occupational Rehabilitation", nr 23 (4), s. 463-475.

Weigl B. (1999). Stereotypy i uprzedzenia etniczne u dzieci i młodzieży. Studium empiryczne. Warszawa: Wydawnictwo Instytutu Psychologii PAN.

Williams J.C., JayLynn S. (2010). Acceptance: An Historical and Conceptual Review. "Imagination Cognition and Personality", nr 30 (1), s. 5-56.

Wirth L. (1938). Urbanism as a Way of Life. „The American Journal of Sociology”, nr 44 (1), s. 1-24.

Zasępa E., Czabała C., Starzomska M. (2005). Postawy wobec niepetnosprawności i osób niepełnosprawnych. „Człowiek Niepełnosprawność Społeczeństwo”, nr 1, s. 23-36.

\title{
PLACE OF RESIDENCE AND ACCEPTANCE OF PEOPLE WITH DISABILITIES
}

\begin{abstract}
The acceptance of people with disabilities in society can be understood as one of the conditions for achieving equal treatment, real participation in social life and personal development, and high quality of life for this group (Kazanowski, Żyta 2020). It can be analyzed in terms of various factors, both external (demographic) and internal. This study, which is part of a larger research project, presents the results of an analysis of the relationship between the place of residence and the level of acceptance of people with disabilities. The assumptions of the ,place-based model' were used, which recognises location as an important factor in socialisation and a product of attitudes (Carter et al. 2016). The study used the Disability Acceptance Scale, which consists of 27 statements and is a tool to measure the level of acceptance of people with disabilities in three dimensions: (1) acceptance of the support given to people with disabilities; (2) acceptance of the inclusion of people with disabilities in institutions of social life; (3) acceptance of the competence of people with disabilities to function in social roles. The research involved 313 people, including 156 women (49.84\%) and 157 men (50.16\%) representing three types of living environments: rural, small town and big city. The research results revealed that respondents declared the highest level of acceptance for including disabled people in institutions of social life (dimension 2), while acceptance of their competences to function in social roles (dimension 3) was at the lowest level. Moreover, statistically significant differences were observed between groups divided by place of residence in terms of the intensity of acceptance for the inclusion of people with disabilities in institutions of social life.
\end{abstract}

Keywords: acceptance, place of residence, disability. 